\section{Jurnal Psikologi Terapan dan Pendidikan}

Vol. 3, No. 2, November 2021, pp. 70-78

ISSN 2715-2456

http://journal.uad.ac.id/index.php/Psikologi/index

\title{
Rumination in children from broken home: Can self-compassion and emotional intelligence reduce rumination?
}

\author{
Amalia Juniarly a,1*, Sayang Ajeng Mardhiyah", ${ }^{\mathrm{b}, 2}$, Nissah Ghina Fitric,3 \\ a,b,cProgram Studi Psikologi, Fakultas Kedokteran, Universitas Sriwijaya, Indralaya \\ *1amaliajuniarly@fk.unsri.ac.id; 2 ajeng_mardhiyah@fk.unsri.ac.id; ${ }^{3}$ nissahghina@gmail.com \\ *Correspondent Author
}

\section{KEYWORDS}

emotional intelligence;

rumination;

self-compassion

\section{KATAKUNCI}

kecerdasan emosi;

ruminasi;

self-compassion
ABSTRACT

Although research on rumination and self-compassion has been done before, none of them examined rumination, self-compassion, and emotional intelligence simultaneously. This study aims to determine the role of self-compassion and emotional intelligence on rumination. The study participants were 200 adolescents aged 10-21 years and whose parents are divorced. Researchers used rumination, selfcompassion and emotional intelligence measuring instrument and distributed the instrument through google form in the data collection process. Multiple regression analysis results indicate that selfcompassion and emotional intelligence have a significant role in reducing rumination. Researchers found that adolescents mostly used mindfulness $(M=18.00 ; S D=3.544)$, reflection $(M=25.59 ; S D=5.364)$, and aspects of self-motivation $(M=17.86 ; S D=2.313)$ to regulate emotions, and feel the benefits of components in everyday life.

Ruminasi pada anak korban broken home: Dapatkah selfcompassion dan kecerdasan emosi mengurangi ruminasi?

Meskipun penelitian tentang ruminasi dan self-compassion telah dilakukan sebelumnya, namun tidak satupun yang meneliti ruminasi, self-compassion, dan kecerdasan emosional secara bersamaan. Penelitian ini bertujuan untuk mengetahui peran self-compassion dan kecerdasan emosional terhadap ruminasi. Partisipan penelitian adalah 200 remaja berusia 10-21 tahun dan memiliki orang tua yang bercerai. Peneliti menggunakan alat ukur ruminasi, self-compassion dan kecerdasan emosi dan dalam proses pengumpulan data melalui google form. Hasil analisis regresi berganda menunjukkan bahwa selfcompassion dan kecerdasan emosional memiliki peran yang signifikan dalam mengurangi ruminasi. Peneliti menemukan bahwa remaja paling banyak menggunakan mindfulness $(M=18,00 ; S D=3,544)$, refleksi $(M=25,59 ; S D=5,364)$, dan aspek motivasi diri $(M=17,86 ; S D=2,313)$ untuk mengatur emosi, dan merasakan manfaat dari komponen tersebut dalam kehidupan sehari-hari.

This is an open-access article under the CC-BY-SA license. 


\section{Introduction}

Parental divorce is the most frightening issue for children, especially adolescents, affecting their psychological condition. Divorce can cause sadness and feelings of loss for children (Hadianti, Nurwati \& Darwis, 2017). Based on data cited from the Mahkamah Agung Republik Indonesia (2020), the marriage divorce data increased in 2017 as much as 472,780 cases, and then it decreased in 2018, that is, by 419,268 cases. Afterward, in 2019, marriage divorce rose again by 468,276 cases, and in 2020, it went down to 444,055 cases. Nonetheless, marriage divorce displayed is still showing considerable amount every year.

Tebeka, Hoertel, Duberbet, and Strat (2016) found that divorce contributes significantly to children's mental health and increases mental disorders' prevalence. Meanwhile, research by Gustavsen, Nayga, and Wu (2016) shows that adolescents with divorced parents tend to have behavioural problems: high consumption of alcohol, tobacco and marijuana, compared to children raised within a stable family unit. From previous research, it is clear that parental divorce has a negative impact on children and adolescent. When the children get to know their parent's separation, their reactions are: shocking, getting angry, grieving over their parents' selfishness, and blaming their parents or other people for the divorce (Iqbal, 2018). Based on the results of research conducted by Besharat, Azemat, and Mohammadian (2018), adolescents with divorced parents have a higher average score of rumination compared to adolescents with non-divorced parents.

Sansone and Sansone (2012) state that rumination is a harmful psychological process; rumination is marked with constant thoughts about the negative content, which generates emotional discomfort. They experience the causes and effect intensely, and it will increase an individual's negative feelings about the incidents that happened to them (Shaleha, Yusainy \& Herani, 2018). Rumination will produce more negative thoughts and later become a cycle (Tatakovsky, 2018) and it does not solve worries but worsens adolescents' view of incidents, feelings, and self (Graham, 2014). Research by Grierson, Hickie, Naismith, and Scott (2016) shows that rumination is a mechanism that underlies mental health problems in the future.

According to Treynor, Gonzalez, and Nolen-Hoeksema (2003), rumination has two components: reflection and brooding. Rumination impacts individuals suffering from depression, contributing to negative thinking, poor problem solving, instrumental behaviour problems, and diminishing social support (Nolen-Hoeksema, Wisco, \& Lyubomirsky, 2008). According to Miranda and Nolen-Hoeksema (2007), rumination can lead to suicide. A passive state, a condition in which an individual is trapped in repeated negative thoughts of adverse events, one of the rumination's components, could cause suicide.

The impact of rumination is so significant that individuals need to learn how to stop the rumination. The strategy of accepting the emotions and not avoiding them can reduce rumination (Evans \& Segerstrom, 2011). One strategy that involves openness and emotional acceptance is self-compassion (Odou \& Brinker, 2014). According to Svendsen, Kvernenes, Wiker and Dundas (2016), self-compassion is a better way of responding than rumination, in which both methods are the contradictive response. It is supported by a research result of which there is a negative correlation between self-compassion and rumination, indicating that the greater self-compassion will cause rumination to decrease.

The research results of Smeets, Neff, Alberts, and Peters (2014) show that selfcompassion can prevent individuals from reflecting on adverse events frequently because self-compassion will reduce negative self-assessment, isolation, and excessive identification of an event. Self-compassion is associated with various characteristics related to mental health so that individuals will need self-compassion in dealing with negative experiences because it reduces sadness and rumination (Odou \& Brinker, 2014).

In his book, Neff (2015) states that people with high self-compassion will contemplate less than individuals having low self-compassion. Rumination is often triggered by feelings of fear, shame, and inadequacy because self-compassion directly counters insecurities, so self- 
compassion can help reduce the harmful effects of rumination. People with past adverse events have memories of unpleasant events and tend to ruminate the events more frequently. As a result, individuals will often get angry. However, self-compassion will help individuals embrace themselves and avoid over-identification with uncomfortable feelings and thoughts and enable individuals to develop the ability to reduce anger and can forgive (Wu, Chi, Zeng, Lin, \& Du., 2019).

Apart from self-compassion, another factor that influences reflection is emotional intelligence. Based on Lanciano, Curci, and Zatton (2010) research, emotional intelligence is related to success in dealing with emotional problems, such as reducing rumination after experiencing an adverse experience. Meanwhile, the research results of Abdollahi and Thalib (2015) show that emotional intelligence is an essential factor affecting the adverse effects of rumination and suicidal thoughts. Salovey and Mayer coined the term emotional intelligence. They define emotional intelligence as the ability to understand and express emotions; assimilate emotions in mind; understand and know emotions; and regulate emotions in self and others (Mayer, Salovey, Caruso \& Cherkasskiy, 2011). Goleman (2015) conceals that emotional intelligence is divided into five regions, e.g., recognizing self-emotion, managing self-emotion, motiving oneself, knowing others' emotions, and building relationships with other people.

Until now, research on rumination and emotional intelligence is still limited. Several studies indirectly discuss rumination and emotional intelligence, including angry rumination as a mediator of the relationship between emotional intelligence abilities and various types of aggression (Sancho, Salguero \& Berrocal, 2016); post-traumatic growth after cancer; the influence of emotional intelligence, management of intrusive rumination, and goal disengagement as mediated by deliberate rumination (Mundey, 2018); and the effect of mindfulness interventions on application-based self-reported rumination, stress, emotional intelligence and life satisfaction in undergraduate students (Ralston, 2016).

From previous research, it is obvious that research with the three variables above is still very rarely conducted, especially in Indonesia. Researchers are interested in examining these three variables. Thus the purpose of this study is to determine the role of self-compassion and emotional intelligence on rumination in children from broken home families.

\section{Method}

The method used in this research is quantitative which is the aims of the research to see the role of two independent variables on one dependent variable. Participants in this study were 200 adolescents having divorced parents aged 10-21 years. Steinberg (2017) divides the adolescent period into three, i.e., early adolescent (10-13 years), middle adolescent (1417 years) and late adolescent (18-21 years). Researchers collected samples using the purposive sampling technique and used social media such as Instagram, Twitter, and Facebook to engage participants. Participation in this study is voluntary. When participants are willing to participate in the research, the researcher links to participants to fill out the research scale online.

This study used a rumination scale, self-compassion scale, and emotional intelligence scale. According to Treynor, Gonzalez, and Nolen-Hoeksema (2003), the rumination scale consist of the rumination components: reflection and brooding. This scale uses a Likert scale, with 18 items and has a correlation coefficient of valid items ranging from $r_{i x}=0.483$ to $r_{i x}=0.819$. The reliability of the rumination scale is 0.936 based on coefficient alpha $(\alpha)$

According to Neff (2015), the self-compassion components consist of self-kindness, common humanity, and mindfulness. The self-compassion scale uses the Likert scale, with 18 items with correlation coefficient of items ranging from $r_{i x}=0.313$ to $r_{i x}=0.764$. The reliability coefficient alpha $(\alpha)$ of the self-compassion scale is 0.904 . 
Meanwhile, to measure emotional intelligence, the researcher used the emotional intelligence scale based on Goleman theory (2015), which consist of five aspects: recognises emotions, manages emotions, motivates, recognises other people's emotions, and builds relationships with others.

This scale uses a Likert with 25 items and has a correlation coefficient of valid items ranging from $r_{i x}=0.312$ to $r_{i x}=0.613$. The reliability coefficient alpha $(\alpha)$ on the emotional intelligence scale is 0.863 . Researchers conducted a descriptive test to determine the mean of each component of rumination, self-compassion, and emotional intelligence. Table 1 . shows the results.

Table 1.

Mean and Standard Deviation for Components/Aspects of Rumination, Self-Compassion and Emotional Intelligence

\begin{tabular}{lcc}
\hline Components/ Aspects & Mean & Std. Deviation \\
\hline Rumination & & \\
Reflection & 25.59 & 5.364 \\
Brooding & 23.69 & 6.196 \\
Self-Compassion & & \\
Self-Kindness & 16.70 & 3.300 \\
Common Humanity & 14.11 & 3.337 \\
Mindfullness & 18.00 & 3.544 \\
Emotional Intelligence & & \\
Recognizing One's Own Emotions & 14.72 & 3.216 \\
Managing Emotions & 16.28 & 2.437 \\
Motivating & 17.86 & 2.313 \\
Recognizing Other People's Emotions & 12.87 & 3.112 \\
Building Relationships with Others & 10.57 & 3.005 \\
\hline
\end{tabular}

Table 1 demonstrate that reflection ( $M=25.59$; $S D=5.364)$ has a mean (average) that is greater than brooding. This result indicates that adolescents from broken home families in this study did much reflection in their lives after their parents divorced. On self-compassion, the mean in mindfulness $(M=18.00 ; S D=3.544)$ is higher than self-kindness and common humanity. So, adolescents from broken families in this study often use mindfulness to deal with their parent's divorce. In emotional intelligence, the mean of self-motivation ( $M=17.86$; $\mathrm{SD}=2.313$ ) is greater than other aspects. So, it can be concluded that victims of broken home families in this study always try to motivate themselves to face reality and to survive the next life after their parent's divorce.

To determine the role of self-compassion and emotional intelligence on rumination, researchers used the multiple regression analysis with the SPSS (Statistic Program for Social Science) computer program 16.00 for Windows.

\section{Results}

To determine the role of self-compassion and emotional intelligence on rumination, researchers used the multiple regression analysis with the SPSS (Statistic Program For Social Science) computer program 16.00 for Windows.

Table 2.

Major Hypothesis Test

\begin{tabular}{llllll}
\hline Hypothesis & R-Square & R-Adjusted & $\boldsymbol{F}$ & $\boldsymbol{p}$ & Description \\
\hline Major & 0.656 & 0.652 & 187.689 & 0.000 & Significant \\
\hline
\end{tabular}


The result of multiple linear regression analysis showed R-Adjusted $=0.652$, with $p=0.000$ $(\mathrm{p}<0.05)$. Thus it can be concluded that there is a significant role of self-compassion and emotional intelligence in facing rumination. The contribution of self-compassion and emotional intelligence to rumination is $65.6 \%$, the remaining $34.4 \%$ being influenced by other factors.

Table 3.

Minor Hypothesis Test

\begin{tabular}{llll}
\hline Hypothesis & Beta & $\boldsymbol{p}$ & Description \\
\hline Minor 1 & -0.894 & 0.000 & Significant \\
Minor 2 & 0.406 & 0.000 & Significant \\
\hline
\end{tabular}

The minor hypothesis testing are divided into two, which are self-compassion and rumination minor hypothesis testing and emotional intelligence and facing rumination minor hypothesis testing. The results of multiple regression analysis showed Beta $=-0.894$ with $p=0.000 \quad(p<0.05)$. Thus it can be concluded that there is a significant contribution of selfcompassion for rumination. The contribution of self-compassion to rumination is $53.1 \%$. The results of multiple regression analysis showed Beta=0.406 with $\mathrm{p}=0.000 \quad(\mathrm{p}<0.05)$. Thus it can be concluded that there is a significant contribution of emotional intelligence to rumination. The contribution of emotional intelligence to rumination is $12.5 \%$

\section{Discussion}

The results showed that self-compassion and emotional intelligence play a significant role in adolescents with divorced parents and have rumination. Neff (2015) states that parents have an essential role in the development of individuals' self-compassion, in which individuals with parents who love to criticize were learn in their early age that such individuals were so bad that they did not deserve to be accepted as they are. In addition to parents, culture also contributed to building individual self-compassion.

Research conducted by Johnson and O'Brien (2013) shows that individuals who improve their self-compassion will likely have lower rumination. In addition, in their research, Proeve, Anton, and Kenny (2018) also state that self-compassion significantly correlates negatively with rumination. It means the level of self-compassion will influence the level of rumination.

Research from $\mathrm{Wu}$ et al (2018) shows that self-compassion positively affects mental health, such as organization and emotional regulation, by controlling anger and aggressive expression. Meanwhile, Krieger, Altenstein, Baetigg, Doerig, and Holtfort (2013) revealing that depression patients show a lower self-compassion level than individual who does not experience depression even when the depression symptoms were controlled.

Self-compassion is widely described as the ability involving recognition and intention to relieve one's own suffering with kindness and attention by without judging oneself, admitting that all humanity has the same condition, that is, all human is fragile and imperfect (Moreira, Gouveia, Carona, Silvia, \& Canavarro, 2014). Self-compassion is compassion directed within oneself. It is similar to when an individual can feel compassion toward other's people suffering. Individuals can also give compassion to themselves when they are facing suffering, regardless of whether this suffering is caused by external circumstances or their own mistakes, failures, and personal incapabilities (Neff \& Germer, 2017).

The results of this study also show that research participants most often practised mindfulness. One of the self-compassion components is mindfulness which is a good cognitive process for individual mental health. Mindfulness and rumination are considered two forms of different attention focus and linked to the different psychological results (Moreira, Gouveia \& Canavaro, 2018). 
This study's results align with the research results by Svendsen et al (2016), which states that the first step to reducing rumination is mindfulness to increase self-compassion. Mindfulness can help individuals avoid being trapped into rumination related to the adverse events or failures that they experienced. Research on mindfulness and rumination has also been conducted by Bluth, Campo, Futch, and Gaylord (2016), and they found that one of the components of self-compassion is mindfulness, which would help individuals to focus on balance and awareness of their current state so that individuals with high awareness will less ruminate. According to $\mathrm{Yu}$ (2017), mindfulness correlates negatively with rumination by altering maladaptive cognitive processes leading to abstract thought into a more adaptive and directed cognitive process. One's cognitive process will become more concrete and specific using mindfulness, indicating reflection so that the high mindfulness can increase reflection to the individual.

This study shows that the subjects in this study did more reflection than brooding from the rumination test results. According to Nolen-Hoeksema, Wisco, and Lyubomirsky (2008), reflection is more adaptive than brooding. Reflection is a neutral component that can reduce adverse effects. Reflection considers the existence of a problem, which also could lead to resolution, and it is a form of adaptive behaviour. Individuals with higher reflection will judge something more neutrally (Shaleha, Yusainy \& Herani, 2018). Research from Samaie and Farahani (2011) shows that the correlation between rumination and self-reflection with stress might be moderated by self-compassion. The high self-compassion functions to weaken the correlation between rumination and stress and strengthen the correlation between selfreflection and stress.

Further analysis shows that emotional intelligence plays a role in rumination. The research results conducted by Liu and Ren's research (2016) shows that emotional intelligence moderates the relationship between rumination and anxiety. When participants have lower levels of emotional intelligence, they simultaneously have higher levels of rumination and anxiety. However, the effect of rumination on anxiety was not significant in the group with high emotional intelligence. The most important finding of this study is that emotional intelligence can play a protective factor in rumination and later in anxiety.

The descriptive test results of this study reveal that the self-motivation aspect of emotional intelligence is dominant. According to Goleman (2015), self-motivation is a person's ability to achieve goals, motivate, control self, and be creative. A person needs to motivate himself to enjoy every challenge and be more productive and effective. Adolescents with self-motivation can achieve their goals in life, handle difficult situations, and are creative under challenging lifetimes after separating from their parents. However, it becomes difficult to be motivated, especially when adolescents experience stress or depression after separating from their parents. If someone feels wrong about being demotivated, the situation worsens, and adolescents will produce more negative thoughts. Adolescents need to beat negative thoughts and avoid them. Consciously replacing negative thoughts with positive words can reduce the fear, anger, worry, or sadness that results from negative thoughts.

Nikolaev (2017) suggests a mindfulness approach to overcoming negative thoughts. Ralston's (2016) research results also prove that mindfulness exercise can improve emotional intelligence, life satisfaction, mindful state and reduce stress and rumination. Following the expectations, it turns out that the research results of Kircaburun, Griffiths, Billieuxc (2019) also show that some ruminations mediate the relationship between emotional intelligence and mindfulness and problematic social media use. Adolescents with higher emotional intelligence are successful in reducing rumination, and ultimately, will also reduce the problems in social media use. In other words, emotional intelligence will increase when people do mindfulness exercises, and mindfulness exercises also help reduce rumination. Rumination, emotional intelligence, and life satisfaction are constructs of psychological well-being, influenced by consciousness. While mindfulness is a component of 
self-compassion.

This study has limitations. Reference studies on rumination, emotional intelligence, and self-compassion are still limited. Besides, researchers still have not found any references to the relationship between self-compassion and emotional intelligence. The length of the parent's separation should also be the control of this study. Future studies need to consider the number of subjects in terms of age and gender.

\section{Conclusion}

The results of this study found that self-compassion can reduce rumination, namely through mindfulness activities. Besides, there are new findings that mindfulness can increase emotional intelligence and reduce rumination. With increased emotional intelligence, rumination will decrease. This study also found that participants in this study used mindfulness, reflection, and self-motivation when dealing with their parents' divorce. According to the results of previous studies that stated that these two variables were proven to reduce children' rumination after their parents separated. Researchers provide suggestions for further research to consider other variables that play a role in rumination, such as social support. Further research can also provide treatment to adolescents with divorced parents to get psychoeducation, training, or mindfulness therapy to reduce rumination by increasing emotional intelligence and self-compassion.

\section{REFERENCES}

Abdollahi, A., \& Talib, M. A. (2015). Emotional intelligence as a mediator between rumination and suicidal ideation among depressed inpatients: The moderating role of suicidal history. Psychiatry research, 228(3), 591-597. https://doi.org/10.1016/j.psychres.2015.05.046.

Besharat, R., Azemat, E. S., \& Mohammadian, A. (2018). A comparative of rumination, healthy locus of control, and emotion regulation in children of divorce and normal children. Practice in Clinical Psycholog, 6(4), 207-214. https://doi.org/10.32598/jpcp.6.4.207.

Bluth, K., Campo, R. A., Futch, W. S., \& Gaylord, S. A. (2016). Age and gender differences in the associations of self-compassion and emotional well-being in a large adolescent sample. Journal of Youth and Adolescence, 46(4), 840-853. https://doi.org/10.1007/s10964016-0567-2.

Evans, D., \& Segerstrom, S. (2011). Why do mindful people worry less? Cognitive Therapy and Research, 35, 505-510. https://doi.org/10.1007/s10608-010-9340-0.

Goleman, D. (2015). Emotional Intelligence: Mengapa EQ lebih penting daripada IQ. Cetakan14. Ahli Bahasa: Hermaya. Jakarta: Gramedia Pustaka Utama.

Graham, L. (2014). How self-compassion beats ruminations. Retrived From https://greatergood.berkeley.edu/article/item/how_self_compassion_beats_ruminatio n tanggal 20 September 2020.

Grierson, A. B., Hickie, I. B., Naismith, S. L., \& Scott, J. (2016). The role of rumination in illness trajectories in youth: Linking trans-diagnostic processes with clinical staging models. Psychological Medicine, 46(12), 2467-2484. https://doi.org/10.1017/S0033291716001392.

Gustavsen, G. W., Nayga, R. M., \& Wu, X. (2016). Effects of parental divorce on teenage children's risk behaviors: Incidence and persistence. Journal of Family and Economic Issues, 37(3), 474-487. https://doi.org/10.007/s10834-015-9460-5.

Hadianti, S. W., Nurwati, N., \& Darwis, R. S. (2017). Resiliensi remaja berprestasi dengan latar belakang orang tuabercerai. Prosiding Penelitian dan Pengabdian Kepada Masyarakat, 4(2), 223-229. https://doi.org/10.24198/jppm.v4i2.14278. 
Iqbal, M. (2018). Psikologi pernikahan. Jakarta: Gema Insani.

Johnson, E. A., \& O'Brien, K. A. (2013). Self-compassion soothes the savage ego-threat system: Effects on negative affect, shame, rumination, and depressive symptoms. Journal of Social and Clinical Psychology, 32(9), 939-963. https://doi.org/10.1521/jscp.2013.32.9.939.

Kircaburun, K., Griffiths, M.D., \& Billieux, J. (2019). Trait emotional intelligence and problematic online behaviors among adolescents: The mediating role of mindfulness, rumination, and depression. Personality and Individual Differences, 89 (2019), 2080213. https://doi.org/10.1016/j.paid.2018.11.024

Krieger, T., Altenstein, D., Baetigg, I., Doerig, N., \& Holtfort, M.G. (2013). Self-compassion in depression: associations with depressive symptoms, rumination, and avoidance in depressed outpatients. Behav Ther, 44(3), 501-2013. https://doi.org/10.1016/j.beth.2013.04.004.

Lanciano,T., Curci, A., \& Zatton, E. (2010). Individual differences on mental rumination : The role of emotional intelligence. Europe's Journal of Psychology, 2, 65-84.

Liu, M., \& Ren, S. (2016). Moderating effect of emotional intelligence on the relationship between rumination and anxiety. Current Psychology, 37 (1), 272-279. https://doi.org/10.1007/s12144-016-9510-7.

Mahkamah Agung Republik Indonesia. (2020). Data perkara peradilan agama tingkat pertama. Retrived From https://badilag.mahkamahagung.go.id/perkara-diterima-dandiputus-pada-tingkat-pertama/data-perkara/perkara-diterima-dan-diputus-pada-tingkatpertama. tanggal 25 Januari 2020.

Mayer, J. D., Salovey, P., Caruso, D. R., \& Cherkasskiy, L. (2012). What is emotional intelligence and why does it matter? Cambridge Handbook of Intelligence. https://dx.doi.org/10.1017/CB09780511977244.027.

Miranda, R., \& Nolen-Hoeksema, S. (2007). Brooding and reflection: Rumination predicts suicidal ideation a one-year follow up in a community sample. Behavior Research and Therapy, 45(12), 3088-3095. https://doi.org/10.1016/j.brat.2007.07.015.

Moreira, H., Gouveia, M. J., \& Canavarro, M. C. (2018). Is mindful parenting associated with adolescents' well-being in early and middle/late adolescence? The mediating role of attachment representations, self-compassion and mindfulness. Journal of Youth and Adolescence. https://doi.org/10.1007/s10964-018-0808-7

Moreira, H., Gouveia, M. J., Carona, C., Silva, N., \& Canavarro, M. C. (2014). Maternal attachment and children's quality of life: The mediating role of self-compassion and parenting stress. Journal of Child and Family Studies, 24(8), 2332- 2344. https://doi.org/10.1007/s10826-014-0036-z.

Mundey, K.A.R. (2018). Posttraumatic growth following cancer: the influence of emotional intelligence, management of intrusive rumination, and goal disengagement as mediated by deliberate rumination (Unpublished Master's Dissertation). Ball State University Muncie, Indiana.

Neff, K. D. (2015). Self-Compassion the proven of being kind to yourself. Harper Collins Publisher.

Neff, K. D. \& Germer, C. (2017). Self-compassion and psychological wellbeing. Oxford Handbook of Compassion Science. Chapter 27. Oxford University Press.

Nikolaev, G. (2017). How to stop negative thoughts with mindfulness. Retrieved From https://mindfulspot.com/how-to-stop-negative-thoughts-with-mindfulness. tanggal 30 November 2020.

Nolen-Hoeksema, S., Wisco, B. E., \& Lyubomirsky, S. (2008). Rethinking rumination. Perspective on Psychological Science, 3(5), 400-424. https://doi.org/10.1111\%2Fj.1745-6924.2008.00088.x. 
Odou, N. \& Brinker, J. (2014). Self-compassion, a better alternative to rumination than distraction as a response to negative mood. Journal of Positive Psychology, Vol. 10, No. 5 , 447-457. https://doi.org/10.1080/17439760.2014.967800.

Proeve, M., Anton, R., \& Kenny, M. (2018). Effects of mindfulness-based cognitive therapy on shame, self-compassionand psychological distress in anxious and depressed patients: A pilot study. The British Psychological Society, 91, 434-449. https://doi.org/10.1111/papt.12170.

Ralston, E. (2016). The influence of an application-based mindfulness intervention on selfreported rumination, stress, emotional intelligence and life satisfaction in undergraduate students. (Dissertation). Manchester Metropolitan University. https://espace.mmu.ac.uk/id/eprint/617889.

Samaie, Gh., \& Farahani, H.A. (2011). Social and Self-compassion as a moderator of the relationship between rumination, self-reflection and stress. Procedia-Social and $\begin{array}{lcr}\text { Behavioral } & \text { Sciences, } & 30 \\ \text { https://doi.org/10.1016/j.sbspro.2011.10.190. }\end{array}$

(2011),

978-982.

Sancho, E.G., Salguero, J.M., \& Berrocal, P.F. (2016). Angry rumination as a mediator of the relationship between ability emotional intelligence and various types of aggression. Personality and Individual Differences, 89, 143-147. http://dx.doi.org/10.1016/j.paid.2015.10.007.

Sansone, R. A., \& Sansone, L. A. (2012). Rumination: Relationship with physical health. Innovation in Clinical Neuroscience, 9(2), 29-34.

Shaleha, R. R. A., Yusainy, C. A., Herani, I. (2018). The mind anchor : Peran trait rumination dalam struktur pengalaman afektif. Mediapsi, 4(1), 47-55. https://doi.org/10.21776/ub.mps.2018.004.01.5.

Smeets, E., Neff, K., Alberts, H., \& Peters, M. (2014). Meeting suffering with kindness: Effects of a brief self- compassion intervention for female college students. Journal of Clinical Psychology, 70(9), 794-807. https://doi.org/10.1002/jclp.22076.

Steinberg. (2017). Adolescence. New York: McGraw Hill.

Svendsen, J. L., Kvernenes, K. V., Wiker, A. S., \& Dundas, I. (2016). Mechanisms of mindfulness: Rumination and self-compassion. Nordic Psychology, 69(2), 71-82. https://doi.org/10.1080/19012276.2016.1171730.

Tatakovsky, M. (2018, Juli). Why ruminating is unhealthy and how to stop. Retrived from https://psychcentral.com/blog/why-ruminating-is-unhealthy-and-how-to-stop. tanggal 14 September 2019

Tebeka, S., Hoertel, N., Dubertret, C., \& Strat Y.L. (2016). Parental divorce and death during childhood and adolescence and its association with mental health. The Journal of Nervous and Mental Disease, 204(9), 678-685. https://doi.org/10.1097/NMD.0000000000000549.

Treynor, W., Gonzales, R., Nolen-Hoeksema, S. (2003). Rumination reconsidered: a psychometric analysis. Cognitive Therapy and Research, 27(3), 247-259. https://doi.org/10.1023/A:1023910315561.

Wu, Q., Chi, P., Zeng, X., Lin, X., \& Du, H. (2019). Roles of anger and rumination in the relationship between self-compassion and forgiveness. Mindfulness, 10(2), 272-278. https://doi.org/10.1007/s12671-018-0971-7.

$\mathrm{Yu}, \mathrm{M}$. (2017). The effects of mindfulness on self-rumination, self-reflection, and depressive symptoms: A research proposal. Behavioural Sciences Undergraduate Journal, 3(1), 1-7. https://doi.org/10.29173/bsuj399. 